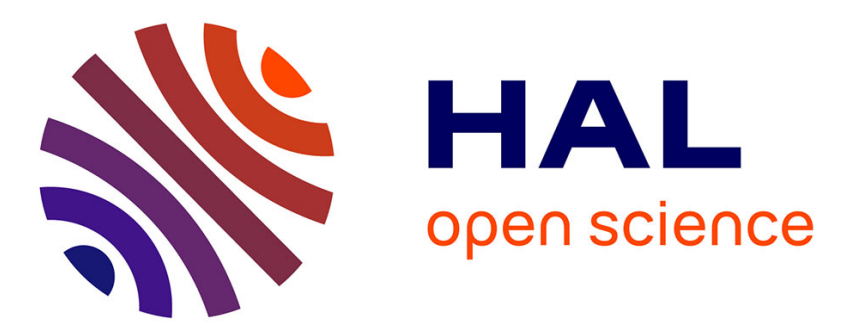

\title{
Unraveling the link between managerial risk-taking and innovation: The mediating role of a risk-taking climate
} Ana García-Granero, Óscar Llopis, Anabel Fernández-Mesa, Joaquín Alegre

\section{To cite this version:}

Ana García-Granero, Óscar Llopis, Anabel Fernández-Mesa, Joaquín Alegre. Unraveling the link between managerial risk-taking and innovation: The mediating role of a risk-taking climate. Journal of Business Research, 2015, 68 (5), pp.1094-1104. 10.1016/j.jbusres.2014.10.012 . hal-01137650

\section{HAL Id: hal-01137650 \\ http://hal.grenoble-em.com/hal-01137650}

Submitted on 31 Mar 2015

HAL is a multi-disciplinary open access archive for the deposit and dissemination of scientific research documents, whether they are published or not. The documents may come from teaching and research institutions in France or abroad, or from public or private research centers.
L'archive ouverte pluridisciplinaire HAL, est destinée au dépôt et à la diffusion de documents scientifiques de niveau recherche, publiés ou non, émanant des établissements d'enseignement et de recherche français ou étrangers, des laboratoires publics ou privés. 


\section{UNRAVELING THE LINK BETWEEN MANAGERIAL RISK-TAKING AND}

INNOVATION: THE MEDIATING ROLE OF RISK-TAKING CLIMATE

Ana García-Granero

Grenoble Ecole Management (GEM), Rue Pierre Sémard, 38003 Grenoble, France

INGENIO (CSIC- Universitat Politècnica de València); Camino de Vera s/n, 46022 Valencia Spain ana.garciagranero@grenoble-em.com

Óscar Llopis

GREThA UMR CNRS 5113, University of Bordeaux, Avenue Leon Duguit, 33608, Pessac Cedex, France INGENIO (CSIC- Universitat Politècnica de València); Camino de Vera s/n, 46022 Valencia Spain oscar.llopis-corcoles@u-bordeaux.fr

Anabel Fernández-Mesa

Departament de Direcció d'Empreses (Facultat d'Economia, Universitat de València)

Avda. Tarongers s/n 46022 Valencia España

anabel.fernandez@uv.es

Joaquín Alegre

Departament de Direcció d'Empreses (Facultat d'Economia, Universitat de València)

Avda. Tarongers s/n 46022 Valencia España

joaquin.alegre@uv.es 


\title{
UNRAVELING THE LINK BETWEEN MANAGERIAL RISK-TAKING AND INNOVATION: THE MEDIATING ROLE OF RISK-TAKING CLIMATE
}

\begin{abstract}
Scholars have proposed that taking risks in organizations is important for explaining innovation performance. Scholars traditionally have analyzed this link from two unconnected perspectives. From a managerial perspective, entrepreneurial orientation and leadership theories have been used to explain the positive relation between risk taking and innovation. From an employee perspective, creativity theory suggests that a risk-taking climate helps to explain innovative behaviors. However, there is little empirical research analyzing this link. This study examines the possibility of a connection between managers' risk-taking propensities, employees' risk-taking climate, and innovation performance. To do so, we test a quantitative model where the impact of the manager' risk-taking propensity on innovation is mediated by its effect on employees' risktaking climate. Structural equation modeling is used to test the research hypotheses on a data set of 182 firms from the Spanish and Italian ceramic tile industry.
\end{abstract}

\section{Keywords}

Innovation performance, managers’' risk-taking, risk-taking climate, signaling theory, social cognitive theory 


\section{UNRAVELING THE LINK BETWEEN MANAGERIAL RISK-TAKING AND \\ INNOVATION: THE MEDIATING ROLE OF A RISK-TAKING CLIMATE}

\section{INTRODUCTION}

The ability of firms to innovate is a primary factor in achieving and sustaining competitive advantage (Nelson and Winter, 1985). Hence, it is widely believed that innovative behaviors should be strongly encouraged across all levels of the organization given that such behaviors are likely to exert a positive influence on organizational effectiveness (Amabile, Barsade, Mueller and Staw, 2005;). The focal point of our research is the relationship between risk-taking and innovation performance from a managerial and an employee perspective. The relationship between risk-taking and innovation performance is particularly fruitful. Substantial research from diverse fields suggests a close link between risk-taking and innovative behaviors in organizational settings (March and Shapira, 1987). Risk-taking and innovation are intertwined due to the nature of creative behaviors in organizations.

From a managerial perspective, the link between risk-taking and innovation performance has been examined using a wide range of approaches, such as entrepreneurial orientation and leadership literatures (Covin and Slevin, 1986; Wu, Levitas and Priem, 2005; Ling, Simsek, Lubatkin and Veiga, 2008). Risk-taking involves the investment of significant resources in activities with significant possibility of failure, which includes incurring heavy debt or making large resource commitments in the hope of reaping potential high benefits (Lumpkin and Dess, 1996; Fernández-Mesa, Alegre and Chiva, 2012). Managers vary in their individual propensity to take risks. This is not trivial given that the evidence shows that a manager's preference for a risky behavior is positively associated with the attainment of higher innovation results (e.g. Ling et al., 2008). Thinking "outside the box" entails a great deal of uncertainty, and bold decisions and actions are often necessary to achieve innovative results. This implies that, compared to risk- 
averse managers, managers with a higher preference for risk will be more likely to consider the potential gains from risky decisions (Ling et al., 2008; Wu, 2008). In March's (1987: 1408) words, "risk-taking is valued, treated as essential to innovation and success".

The literature on creativity provides a different, yet related, view of this relation, being more focused on the personal and contextual factors explaining why employees engage in innovative activities (e.g.: Amabile, Conti, Coon, Lazenby and Herron, 1996; Oldham and Cummings, 1996). A fundamental idea is that creative behaviors are about challenging the status quo of given aspect of the organization. From the employee's point of view, the consequences of such challenges are uncertain. In fact, those employees displaying innovative behaviors may face negative consequences if they fail (Zhou and George, 2001). For instance, Janssen (2003) demonstrates that innovative employees are likely to come into conflict with co-workers because the worker promoting a new idea is challenging established courses of action and the assumptions of co-workers. It is likely that resistance, in the form of work conflicts, will arise.

Although work from both views has significantly advanced our understanding of the nature of the link between risk-taking and innovative performance, observation of this relation through a combined lens is lacking. We believe that it would be more informative to explore the effects of risk-taking on innovation performance at different levels of the organization. We would argue that managers' risk-taking behavior not only exerts a direct effect on innovation performance but also that the organizational risk-taking climate benefits due to a positive signaling effect deriving from managers' risk-taking attitudes.

The paper is structured as follows. First, we provide a brief theoretical review of innovation in organizational contexts. Second, we introduce the relevance of managers' and employees' risk-taking for fostering organizational innovation. In the third section, we present the conceptual model and develop our hypotheses. The last two sections test our model on a 
sample of 182 companies for the Spanish and Italian ceramics sector, and present our results, findings, limitations and some managerial implications.

\section{CONCEPTUAL BACKGROUND}

\section{Innovation Performance}

For firms innovation is central to achieving sustained competitive advantage (Teece, Pisano and Shuen, 1997). The evolution of an increasingly complex environment has made innovation an unavoidable option in plans to increase the performance, continuing growth and survival of firms (Daellenbach, McCarthy and Schoenecker, 1999). Innovation can be defined as the successful implementation of new ideas (Amabile et al., 1996). This understanding includes novelty and usability as two indispensable conditions. Thus, innovation requires new ways to solve problems and achievement of commercial success.

Innovations can be either product or process innovations (OECD, 2005; Martínez-Ros and Labeaga, 2009). Product innovation is understood as a product or service introduced to meet the needs of the market or an external user; process innovation is understood as a new element introduced into production operations or functions (Damanpour and Gopalakrishnan, 2001). Both types of innovation are closely related, and although firms may be more focused on product innovation, process innovation may be necessary for the successful implementation of their new products (Martínez-Ros and Labeaga, 2009).

Although significant efforts have been invested in trying to understand the factors underlying innovation performance, the process carries high failure rates ( $\mathrm{Wu}$ et al., 2005). Despite the difficulties involved in producing innovation, it is one of the main drivers of organizational growth, thus it is important to have a more fine-grained understanding of its determinants.

\section{Managers' Risk-Taking Propensity}


The determinants of innovation include exogenous factors such as the firm's external environment, and more malleable aspects such as the organizational culture, structure, and strategy (Papadakis, Lioukas and Chambers, 1998; Vega-Jurado, Gutiérrez-Gracia and Fernández-de-Lucio, 2008). In particular, leaders have been repeatedly recognized as strategic decision makers able to identify opportunities and make the right decisions to encourage innovation (Elenkov, Judge and Wright, 2005; Aleviev, Jansen, Van den Bosch and Volverda, 2010). Firms' managers involved in decision making are faced with the uncertainty intrinsic to innovation activities. Innovation needs investments of time, effort, and resources, such as increases in $\mathrm{R} \& \mathrm{D}$ expenses and greater allocation of management attention, although the distribution of the returns from these investments is unknown (Wu et al., 2005; Ling et al., 2008). This uncertainty and the significant possibilities of failure often lead to risk averse behaviors and under-investment in innovation (Finkelstein, 1992; Wu, 2008). However, expectations of potentially high returns drive many managers to opt for risky solutions and to focus on the potential benefits of innovation rather than the potential losses (Ling et al., 2008).

Several streams of research propose that managers' risk-taking propensity can make a difference in defining the ability of firms to innovate. For instance, the entrepreneurial orientation literature conceptualizes risk-taking as one of the dimensions affecting the firm's strategic position, that is, the extent to which top managers are inclined to take business related risks (Covin and Slevin, 1986). Scholars in this tradition generally focus on how an entrepreneurial orientation heightens performance (Zahra and Covin, 1995; Madsen, 2007).

Scholars using the upper echelon perspective study risk-taking propensity in managers and top management teams according to characteristics such as tenure and age, and their effects on innovation performance (Bantel and Jackson, 1989; Wu et al., 2005; Liu et al., 2012). Work in the leadership literature assesses more directly how the propensity of top management teams for risk-taking influences performance (Papadakis et al., 1998; Peterson, Smith, Martorana and 
Owens, 2003), and specifically innovative processes and outcomes (Ling et al., 2008). In general, results confirm that managers biased towards risk-taking behaviors are more likely to obtain better innovation results.

Although managers' risk-taking propensity appears pivotal for explaining innovation performance in organizations, the mechanisms linking it to organizational innovation performance remain unclear. Contextual factors in the organization may play a significant role.

\section{Risk-Taking Climate}

Although there are several ways to approach the different contextual features of organizations, researchers often use the notion of organizational climate to assess the social features of workplaces that facilitate or inhibit certain behaviors (Schneider and Reichers, 1983) The organizational climate is a multidimensional construct that encompasses a wide range of organizational realities (James and McIntyre, 1996). According to Denison (1996), organizational climate concerns those aspects of the social environment perceived by organizational members.

The concept of organizational climate has become prominent in management studies, and has been deconstructed into specific dimensions (Schneider and Reichers, 1983; Spagnoli et al., 2012), depending on the phenomenon under study. For instance, climate scholars have developed a construct to measure climates for justice (Naumann and Bennett, 2000), creativity (Gilson and Shalley, 2004), and innovation (Pirola-Merlo and Mann, 2004), among others. Many of these "climates" occur simultaneously in an organization (Kuenzi and Schminke, 2009), and measure different realities of the organizational environment. Employees conceive the climate of the organization as the source of cues about how to behave. For instance, Gilson and Shalley (2004) found that team members who were more engaged in the creative process reported their team climate being more supportive of creativity. 
A particular facet of the organizational climate that is likely to influence employees' innovative performance is the firms' risk-taking climate. Employees fear failure (Zhou and George, 2001), and innovating in an organizational setting can be viewed as risky behavior. Risktaking means uncertainty about the potential outcomes of one's decision (Sitkin and Pablo, 1992). This is a barrier that can be scaled if employees perceive that the organizational climate supports risk-taking and innovative behaviors.

\section{HYPOTHESES}

Based on the discussion above, we propose a conceptual model which is depicted in Figure 1. It integrates the effects of management risk-taking propensity, and a risk-taking climate, on innovation performance. Specifically, it proposes that managers' risk-taking propensity better explains innovation if the mediating effect of an organizational risk-taking climate is considered. Managers' risk-taking propensity may not only exert a direct influence on innovation performance but also may create and maintain a particular facet of the organizational climate that helps employees to cope with the risks associated with engaging in innovative behaviors.

Insert Figure 1 about here

\section{Managers' Risk-Taking Propensity and Risk-Taking Climate}

There is a body of work emphasizing the critical role of managers in shaping particular facets of the organizational climate (Grojean, Resick, Dickson and Smith, 2004). The actions of managers regarding risk-taking are likely to have a considerable influence over the risk-taking climate in the organization. In this section we propose a series of mechanisms by which leaders' 
risk-taking propensity can influence a shared perception of risk-taking in the organization, and therefore, the risk-taking climate.

First, research on organizational behavior indicates that managers' behaviors are a powerful communicating mechanism that conveys the assumptions of the organizational climate Grojean et al., 2004). Managers' behaviors are taken as models of appropriate behaviors in particular situations. According to social cognitive theory (Bandura, 1986), individuals have the capacity to learn vicariously. Vicarious learning refers to the process of learning by observing the behavior of others and its consequences (Bandura, 2001). For instance, House and Shamir (1993) suggest that vicarious learning is an important mechanisms through which the values of the organization are transmitted from managers to employees. We extend this rationale to argue that those managers more prone to take risks in their organizational decisions shape the risk-taking climate of the organization. As a consequence, employees will perceive the climate as more tolerant of risk-taking.

Another transmitting mechanism is anchored in signaling theory (Spence, 1973). Signaling theory refers to behaviors that convey information about an individual's intentions and abilities. Management scholars have applied signaling theory to argue that, in organizations, managers are powerful signalers of desirable behaviors (Connelly, Certo, Ireland and Reutzel, 2011). The main rationale for signaling theory is information asymmetry. Employees may not have full information about how they are expected to behave in particular situations (e.g. taking a risky decision versus being conservative). In order to reduce information asymmetry, managers may consciously decide to emit signals to observers. In the particular case of risk-taking, managers' risk-taking propensity may be a powerful signal to stress the importance of risk-taking behaviors among employees. Signal receivers (here, employees), will use these signals to make more informed decisions (Cohen and Dean, 2005). Taken together, the above arguments allow us to propose the following hypothesis: 
Hypothesis 1: Managerial risk-taking propensity is positively related to risk-taking climate.

\section{Risk-Taking Climate and Innovation Performance}

Research on creativity and innovation indicates that creative efforts require substantial investment of time and energy on the part of the individual (Redmond, Mumford and Teach, 1993). The ultimate decision to engage in innovative behaviors belongs to the employee, and willingness and motivation to do so may be influenced by a number of organizational characteristics (Chen \& Huang; 2009). According to Yuan and Woodman (2010:324), innovative behavior is defined as “as an employee's intentional introduction or application of new ideas, products, processes, and procedures to his or her work role, work unit, or organization". Employees deciding to search for and apply new technologies for their daily work, or suggest new ways to achieve objectives in their organization, are examples of such behaviors. These types of behaviors are likely to exert a positive effect on the organizations' overall innovation performance.

However, innovative behaviors are closely linked to risk-taking. Engaging in innovative behavior requires feeling comfortable with taking risks or at least the ability to tolerate a degree of risk. Employees may lack the motivation to take risks in their organizations for a number of reasons. Given that employees' actions are guided by expectations about the consequences of their behaviors (Vroom, 1964), the perceived costs of introducing a new idea or procedure may overshadow its potential benefits. Among those costs, challenging the organizational "status quo" is prominent. Implementing or suggesting a novel procedure or idea means that existing ones are challenged. Organizations are "a stabilizing force" however (Klein and Knight, 2005), and organizational norms and routines encourage maintenance of the status quo. Innovative employees may encounter barriers (e.g. conflicts with colleagues) to their new ideas when they challenge those norms (Janssen, 2003). 
A contextual factor that can help to overcome the costs of engaging in innovation performance is a, organizational climate favorable to risk-taking (James and McIntyre, 1996). If employees perceive that a certain behavior is approved of by colleagues, their willingness to perform that particular behavior will be increased. In the case of innovation performance, it is reasonable to expect that an organizational climate that supports risk-taking will enhance the willingness of employees to engage in innovative behaviors (Ekvall, 1996). Organizational members will be more likely understand that innovativeness is a desirable behavior in the organization, and will psychologically feel more secure about trial and error attempts (Yuan and Woodman, 2010). It is reasonable to expect that employees that perceive a favorable risk-taking climate will enable the integration of risky behaviors, which will benefit the organizations overall innovation performance. To sum up, we propose that those organizations with a stronger risktaking climate will show higher levels of innovation performance, compared to organizations with weaker risk-taking climates. That is,

Hypothesis 2: There is a positive relationship between the risk-taking climate and innovation performance.

\section{Manager's Risk-Taking Propensity and Innovation Performance: a case for partial mediation}

Scholars quite widely assume that the strategies of top managers chime with the organizational level aims, and that top managers' personalities and behaviors have a direct influence on organizational outcomes (Wu, Levitas and Priem, 2005; Aleviev et al., 2010). Real change, however, emerges at lower levels within the organizational structure (Jelinek, 2003). In this sense, learning and cognitive theories state that senior executives with strong convictions about innovation are not enough to generate the organizational change required to achieve novelty and enable innovation. For this to occur, a critical mass of shared beliefs must be 
generated (Sidhu, Commandeur and Volberda, 2007). The role of employees is essential to achieve an ultimately desirable impact of managerial action on the firm's overall results.

Specifically, risk-taking propensity should be a relevant characteristic in manager's personal schemata in order to induce an innovative logic in the firm. However, following the above arguments, we would argue that this on its own is not sufficient for the development of innovation. All firm employees are potential sources of new ideas that could shape the products and processes generated by the company (Redmond, Mumford, and Teach, 1993). However, the barriers to innovating, which inevitably involve risk, are high. Thus, for innovative behaviors to emerge, employees' must have clear perceptions of the degree of risk that will be tolerated (James and McIntyre, 1996). A climate supportive of risk-taking will determine that an employee willing to experiment with new ideas will put these ideas into practice.

The creation of such a climate is down to the manager (Peterson et al., 2003). Conveyed via unconscious or conscious signals, managers' acceptance of risk can have a positive impact on the firm's employees (Spence, 1973; Bandura, 1986). In this sense, risk-taking tendencies should cascade down the organizational hierarchy. Manager's keen on strong rules of conduct can trigger specific employee behaviors. Generating individual innovative behavior will promote innovation at the organizational level (Ling et al., 2008).

We would argue that managers have the power to shape the organization climate by making decisions that show a propensity for risk-taking. Once these decisions are realized there is a greater chance that innovation will emerge from lower levels in the organization. We contribute to existing work by analyzing the direct link between managers' risk-taking and innovation, arguing that innovation is not only determined directly by managerial decisions but is also a function of the risk-taking climate. In particular, we argue that managers' risk-taking impacts on innovation by shaping the risk-taking climate in the organization. In this sense, the 
risk-taking climate will mediate the relationship between manager's risk propensity and innovation performance. Thus:

Hypothesis 3: The relationship between managerial risk-taking and innovation performance is mediated by the risk-taking climate.

\section{RESEARCH METHODS}

\section{Data Collection and Research Site}

Our research hypothesis is tested on a single industry, ceramic tile manufacture, in Italy and Spain. Italian and Spanish ceramic tile producers have several things in common. Most are small and medium sized enterprises (SMEs) with a maximum of 250 workers, and generally are geographically concentrated in industrial districts (Enright and Tenti, 1990). The Italian ceramic tile industrial district is located in Sassuolo (Northern Italy) and the Spanish district is in Castellón (Eastern Spain). By focusing our analysis on just one sector we can examine its particular characteristics in more depth and their influence on innovation patterns. A one sector study also reduces the range of extraneous variations in the data which could influence the constructs of interest (Coombs, Narandren and Richards, 1996; Santarelli and Piergiovanni, 1996). On the other hand, it limits generalization to other sectors but we consider that the disadvantages are outweighed by the advantages offered by this approach.

Specifically, in the production of ceramic tiles, technological accumulation is generated mainly by (1) design, construction and operation of complex production systems (scale-intensive path), and (2) knowledge, skills and techniques of chemical research emerging (science-based path). Previous studies provide evidence that Italian and Spanish ceramic tile producers are relatively innovative (Chiva and Alegre, 2009). These studies conclude that the enamel, and the tile design are the most important areas for product improvements (Meyer-Stamer, Maggi and Seibel, 2004; Hervas-Oliver, Jackson and Tomlinson, 2011). 
The fieldwork for the present study was conducted in June to November 2004. We held surveys through personal interviews in each company. We received a total of 182 completed questionnaires, 101 from Spanish firms and 81 from Italian firms, which represents around 50\% of the populations under study in both the Italian and the Spanish subsamples (Chamber of Commerce of Valencia, 2004). The number of responses and the response rate can be considered satisfactory (Spector, 1992; Williams, Gavin and Hartman, 2004). To encourage a higher response rate we offered participating firms a report of our main results.

We reduced the risk of common method variance (CMV) by collecting responses from three different sources in each company. Basing measures on different sources helps to control for CMV because it diminishes the effects of consistency motifs or social desirability tendencies (Podsakoff, MacKenzie and Podsakoff, 2012). In our study, CEOs responded to aspects of entrepreneurship (Escribá-Esteve, Sánchez-Peinado and Sánchez-Peinado, 2008); production and / or research. R\&D managers responded to questions related to innovation performance since the production manager is the person most knowledgeable about innovation activity (Calantone et al., 2002). Human resource managers responded to questions about the organizational climate (Wang, 2008). We conducted a Harman's single-factor test (Podsakoff and Organ 1986; Podsakoff, MacKenzie, Lee and Podsakoff, 2003) to check that variance was not due just to first factors. Finally, to check for non-response bias, we compared sales turnover and number of employees in respondent and non-respondent firms; no significant differences were revealed.

\section{Measures}

Managerial risk-taking. We use the risk-taking dimension in Covin and Slevins's (1986) entrepreneurial orientation (EO) scale. This scale was developed to reflect "the organizational processes, methods and styles that firms use to act entrepreneurially”(Lumpkin and Dess, 1996, p. 139). Risk-taking is one of the three dimensions comprising the EO scale together with 
innovativeness and proactiveness. Specifically, risk-taking involves taking bold actions by venturing into the unknown, borrowing heavily, and/or committing significant resources to ventures in uncertain environments. Although all three dimensions are highly related, empirical evidence shows that each dimension is conceptually different and partly independent of the other dimensions (Lyon, Lumpkin and Dess, 2000; Naldi, Nordqvist, Sjöberg and Wiklund, 2007). These items were applied using a 7-point Likert scale (see annex).

To measure risk-taking climate we use the items proposed in the literature using a 7-point Likert scale. Isaksen et al. (1999) propose several items to measure employees' risk-taking climate while Amabile et al. (1996) measure how to reinforce creativity through employees' risktaking. Our proposed scale is presented in the annex.

Innovation performance is measured using the scale provided in the OECD's (2005) Oslo Manual to assess the economic objectives of innovation. We compared innovation performance with competitors on several items (see annex) on a 7-point Likert scale. We operationalized innovation performance as a second-order factor construction, integrated by three different dimensions: product innovation efficacy, process innovation efficacy, and innovation project efficiency. Product and process innovation efficacy reflects the degree of success of an innovation. Innovation project efficiency reflects the effort carried out to achieve that degree of success. These dimensions have been widely discussed in innovation research (Brown and Eisenhardt 1995; Chiesa, Coughlan and Voss, 1996).

Company size and company location are used as control variables. Belonging to a particular industrial district provides access to a labor market as well as a number of advantages associated with the adoption of a specific institutional framework. Therefore we control for whether belonging or not to an industrial district has a significant impact on the firm's innovation performance $(1=$ firms located in Italy, 2 = firms located in Spain $)$. At the same time, numerous 
studies suggest that firm size also affects innovation results, so we asked about the number of the firm's employees according to the four categories of firm size suggested by the European Commission (OECD, 2005).

\section{RESULTS}

\section{Psychometric Properties}

The psychometric properties of the measurement scales were assessed in accordance with accepted practice (Gerbing and Anderson, 1988; Tippins and Sohi, 2003), including content validity, reliability, discriminant validity, convergent validity, and scale dimensionality. Table 1 presents the factor correlations, means, and standard deviations.

Content validity was established through a review of the literature, and interviews with four ceramic tile industry experts. We computed the coefficient alpha and composite reliability indicator to assess scale reliability (Fornell and Larcker, 1981). All scales achieved acceptable coefficient alphas and composite reliability indicators of at least 0.70 (Table 1).

Insert Table 1 about here

Discriminant validity was assessed through confirmatory factor analysis by comparing the $\chi^{2}$ differences between a constrained confirmatory factor model and an interfactor correlation set at 1 (indicating they are the same construct) and an unconstrained model with an interfactor correlation set to be free. All $\chi^{2}$ differences were significant, providing evidence of discriminant validity (Anderson and Gerbing 1988; Gatignon, Tushman, Smith and Anderson, 2002; Tippins and Sohi, 2003).

Confirmatory factor analysis was used also to establish convergent validity by confirming that all scale items loaded significantly on their construct factors (Anderson and Gerbing, 1988). Figure 2 shows the confirmatory factor analysis of the second order factor. Convergent validity 
was confirmed by comparing the $\chi^{2}$ differences between a constrained confirmatory factor model with an interfactor correlation set at 0 (indicating no relationship between the two constructs) and an unconstrained model with an interfactor correlation set free. All $\chi^{2}$ differences were significant, providing evidence of convergent validity (Gatignon et al., 2002).

\section{Insert Figure 2 about here}

We checked the dimensionality of the constructs through the loadings of the measurement items on first-order factors, and the loadings of the first-order factors on second-order factors. All loadings were above 0.40 and significant at $\mathrm{p}<0.001$. No cross-loadings emerged.

\section{Testing the Research Hypotheses}

We tested for the presence of a mediating effect by performing competing model analysis (see figures 3 and 4). Structural Equation Modeling is used to perform the analysis (Woodside, 2013) with the EQS 6.1 tool. The first model (direct effect) examines the direct relationship between managerial risk-taking and innovation performance. The $\chi^{2}$ statistic for each model is significant, and the other relevant indices suggest a good overall fit (Tippins and Sohi, 2003).

Insert figure 3 about here

Insert figure 4 about here

First, the direct effect model was tested and found to be satisfactory. There is evidence of a positive link between managerial risk-taking propensity and innovation performance. Second, the inclusion in the analysis of risk-taking climate helps to explain this positive link: risk-taking climate acts as a mediating variable that boosts the positive effect (Grewal and Slotegraaf, 2007). 
Its mediating effect on the relationship between managerial risk-taking propensity and innovation performance is demonstrated by the following sequence suggested by Tippins and Sohi (2003): (1) the partial mediation model explains more of the variance of the dependent variable than the direct model $\left(\mathrm{R}^{2}=0,487\right.$ vs. $\left.\mathrm{R}^{2}=0,324\right)$; (2) there is a positive relationship between managerial risk-taking and risk-taking climate; (3) there is a positive relationship between risk-taking climate and innovation performance; and (4) the significant relationship between managerial risk-taking and innovation performance indicated in the direct effect model becomes lower in the partial mediation model.

Statements (1)-(4) provide compelling evidence of a clear mediating effect of risk-taking climate on the relationship between managerial risk-taking and innovation performance. Thus, the partial mediation model represents a significant contribution to our understanding of the positive influence-supported by the theory and previous empirical research—of managerial risk-taking on innovation performance. The positive impact of managerial risk-taking propensity on innovation performance is mediated by the firm's risk-taking climate. These results provide support for our research hypothesis.

\section{DISCUSSION}

The attitude of managers towards risk-taking has received considerable attention within the literature. In part, the significance of risk-taking is due to its noteworthy effects on innovation performance. Generally, managers characterized by risk-taking behavior do not constrain their actions to the unpredictable consequences of innovation decisions. In deciding whether to allocate resources or to direct processes towards the development of new products and processes, risk-taking prone managers are more willing. This idea chimes with prior empirical studies analyzing the relationship between managerial risk-taking and innovative results (e.g. Ling et al., 2008). 
However, these studies focus on the direct link between managerial risk and innovation, even though there are reasons to believe that they do not fully capture the complexities involved in this relationship. Studies anchored in the organizational climate literature suggest that organizations that encourage risk-taking can influence employees' behaviors towards innovation, thus benefiting the organization's overall innovation performance (Gilson and Shalley, 2004; Yuan and Woodman, 2010). This paper takes account of this literature and ultimately shows the relationship between managers' risk-taking propensity, organizational climate, and innovation.

First, the present research provides empirical evidence that managerial risk-taking is positively related to risk-taking climate. In developing our theoretical framework we considered social cognitive and signaling theory as two theories that explain the mechanisms through which risk-taking can be transmitted from the upper to the lower echelons. While the former assumes that individuals learn vicariously, the latter assumes information asymmetry and expects managers to consciously emit signals to employees. Though based on distinct assumptions, both theories support the relevance of the manager's role in generating a climate where risk-taking is supported.

Second, this study provides empirical evidence that the organizations' risk-taking climate enhances innovation performance. Scholars studying organizational climate pay attention to the distinct dimensions integrating this concept, such as innovation climate. For instance, King et al. (2007) show that a climate for innovation exerts a positive effect on organizational performance. However, although some studies have theoretically reasoned that a risk-taking climate can affect innovative behavior and outcomes (Ekvall, 1996; Yuan and Woodman, 2010), empirical tests analyzing the relationship between risk-taking climate and innovation performance are surprisingly lacking. 
Third, we show that manager's risk-taking propensity has an indirect positive effect on firm's innovation performance, which is mediated by risk-taking climate. Hence, risk-taking climate plays a pivotal role in ultimately explaining the effect of manager's tendency towards risk on innovation outputs. Companies with managers able to project their risk-taking propensity on the rest of the organization's employees are capable to perform better than other firms.

In sum, this study shows that the role of employees' risk-taking climate is a determinant mediating the relationship between manager's risk-taking and innovation performance. On the one hand, the results of this study contribute to upper echelon and other leadership behavior theories by demonstrating that the effect of manager's risk-taking on innovation is not direct but rather is mediated by a relevant contextual factor - risk-taking climate. On the other hand, this study contributes to the literature on organizational climate. In this case, we show empirically that risk-taking climate has a significant effect on innovation performance.

This study has implications for practitioners. Risk is frequently described as an essential ingredient for the achievement of innovation. However, managers' acknowledgement of the relevance of risk taking is not sufficient to achieve organizational innovation. Managers must be able to translate their proactiveness towards risk to other employees, to encourage a creative and biased climate with the potential to generate innovative behaviors. This paper underlines the relevance of supporting risk-taking climates and their effects on innovation performance.

The investigation in this paper is particularly relevant to the problem faced by many organizations in relation to manager's turnover. Organizations relying on key managers for relevant decisions are confronted by uncertainty if they leave the firm. For instance, consider a manager characterized for an affinity for decisions involving high risks. If this input is significant for innovation results then if the manager leaves the firm this would be a huge loss. It is in the interests of firms to motivate risk-taking behavior among all their employees. 
Lastly, in the specific context of this study, that is ceramic tile firms, it is particularly relevant that risk tolerance is widespread in companies. Most of these firms are family owned and especially vulnerable to changes of management. The manager has considerable discretion to moderate the organizational climate to recognize, assess, and tolerate innovation, risk, and creativity among employees.

This study has some limitations including the nature of the data, which were collected at one moment in time. This type of research, understood as cross-sectional, becomes problematic when data change over time. However, in future research we plan longitudinal studies to evaluate possible variations over time and solve endogeneity problems.

Another limitation is that the study is of a single industry which means that extrapolation of results to other sectors should be done with extreme caution. We need more research on other industries. Moreover, the ceramic tile industry is characterized by SMEs, which means that managers have a large degree of discretion over innovation outcomes. Future research could focus on large enterprises where the manager's influence on innovation is usually lower and the creation of a climate of risk could have greater implications.

The use of self-reported innovation performance can also be considered a limitation (Venkatraman, 1989). It would be interesting to collect additional objective dependent measures to avoid possible biases and add robustness to our results. Moreover, qualitative research could also improve our research by providing a deeper understanding of the object of study (Chiva and Alegre, 2009).

Lastly, it would be interesting to delve further into the black box. Decentralization of decision making has been suggested as a managerial practice that empowers employees and leaves space for novel and disruptive ideas entailing high degrees of risk (Jansen et al., 2006). Also, dynamic environments have been described as pushing firms towards the generation of 
innovations because of the heightened possibility of product obsolescence (Sidhu, Volberda and Commandeur, 2004). Hence, further research could benefit from deeper analysis of the contingent effects of these practices in the relationship between manager's risk-taking propensity, risk-taking climate, and innovation performance.

\section{ACKNOWLEDGEMENTS}

The authors are grateful for the finance received by the Spanish Ministry of Science and Innovation (ECO2011-28706, ECO2011-28749 and ECO2011-29863) to carry out this research. Moreover, acknowledgements are due to CSIC for funding Ana García-Granero and Óscar Llopis research grant (JAE-Predoc del Programa «Junta para la Ampliación de Estudios») cofinanced by the ESF. 


\section{REFERENCES}

Aleviev, A.S., Jansen, J.J.P., Van den Bosch, F.A.J., \& Volberda, H.W. (2010). Top Management Team Advice Seeking and Exploratory Innovation: The Moderating Role of TMT Heterogeneity, Journal of Management Studies, 47(7), 1343-1364.

Amabile, T. M, Barsade, S. G., Mueller, J. S., \& Staw, B. M. (2005). Affect and creativity at work. Administrative Science Quarterly, 50(3), 367-403.

Amabile, T.M., Conti, R., Coon, H., Lazenby, J., \& Herron, M. (1996). Assessing the work environment for creativity, Academy of Management Journal, 39(5), 1154-1184.

Anderson, J.C., \& Gerbing, D.W. (1988). Structural Equation Modeling in Practice: A Review and Recommended Two-Step Approach, Psychological bulletin, 103(3), 411-423.

Bandura, A. (1986). Social Foundations of Thought and Action: A Social Cognitive Theory $\left(1^{\text {st }}\right.$ ed.). Prentice Hall.

Bandura, A. (2001). Social cognitive theory: an agentic perspective. Annual Review of Psychology, 52, 1-26.

Bantel, K., \& Jackson, S.E. (1989). Top management and innovations in banking: Does the demography of the top team make a difference?. Strategic Management Journal, 10, 107124.

Brown, S.L., \& Eisenhardt, K.M. (1995). Product development: Past research, present findings, and future directions. Academy of Management Review, 20, 343-378.

Calantone, R.J., Cavusgil, S.T., Zhao, Y. (2002). Learning orientation, firm innovation capability, and firm performance. Industrial Marketing Management, 31(6), 515-524.

Chamber of Commerce of Valencia (2004). Informe de la nueva economía global y su incidencia en los sectores tradicionales de la Comunidad Valenciana. Valencia: Chamber of Commerce of Valencia.

Chen, C. J., \& Huang, J. W. (2009). Strategic human resource practices and innovation performance-The mediating role of knowledge management capacity. Journal of Business Research, 62(1), 104-114.

Chiesa, V. Coughlan, P., \& Voss, C.A. (1996). Development of a technological innovation audit. $R \& D$ Management, 13, 105-136.

Chiva, C., \& Alegre, J. (2009). Investment in Design and Firm Performance: The Mediating Role of Design Management. Journal of Product Innovation Management, 26, 424-440.

Cohen, B. D., \& Dean, T. J. (2005). Information asymmetry and investor valuation of IPOs: top management team legitimacy as a capital market signal. Strategic Management Journal, 26(7), 683-690.

Connelly, B.L., Certo, S.T., Ireland, R. D., \& Reutzel, C. R. (2011). Signaling Theory: A Review and Assessment. Journal of Management, 37(1), 39-67.

Coombs, R., Narandren, P., \& Richards, A. (1996). A literature-based innovation output indicator, Research Policy, 25(3), 403-413.

Covin, J. G., \& Slevin, D.P. (1986). The development and testing of an organizational-level entrepreneurship scale. Frontiers of Entrepreneurship Research. MA: Wellesley. 
Daellenbach, U.S., McCarthy, A.M., Schoenecker, T.S. (1999). Commitment to innovation: the impact of top management team characteristics, $R \& D$ Management, 29 (3), 199-208.

Damanpour, F., \& Gopalakrishnan, G. (2001). The Dynamics of the Adoption of Product and Process Innovations in Organizations. Journal of Management Studies, 38(1), 45-65.

Denison, D.R. (1996). What is the Difference between Organizational Culture and Organizational Climate? A Native's Point of View on a Decade of Paradigm Wars. Academy of Management Review, 21(3), 619-654.

Ehrhart, M. G. (2004). Leadership and Procedural Justice Climate as Antecedents of Unit-level Organizational Citizenship Behavior. Personnel Psychology, 57(1), 61-94.

Elenkov, D.S, Judge, W., Wright, P. (2005). Strategic leadership and executive innovation influence: an international multi-cluster comparative study. Strategic Management Journal, $26,665-682$.

Ekvall, G. (1996). Organizational climate for creativity and innovation. European Journal of Work and Organizational Psychology, 5(1), 105-123.

Enright, M.J. \& Tenti, P. (1990). How the diamond works: The Italian ceramic tile industry. Harvard Business Review, 68, 90-91.

Escribá-Esteve, A., Sánchez-Peinado, L., \& Sánchez-Peinado, E. (2008). Moderating influences on the firm's strategic orientation-performance relationship. International Small Business Journal, 26(4), 463-489.

Finkelstein, S. (1992). Power in top management teams: dimensions, measurement, and validation. Academy of Management Journal, 35 (3), 505-538.

Fernández-Mesa, A., Alegre-Vidal, J., \& Chiva-Gómez, R. (2012). Orientación emprendedora, capacidad de aprendizaje organizativo y desempeño innovador. Journal of Technology Management and Innovation, 7(2), 157-170.

Fornell, C., \& Larcker, D. (1981). Evaluating Structural Equation Models with Unobservable Variables and Measurement Error, Journal of Marketing Research, 18, 39-50.

Gatignon, H., Tushman, M.L., Smith, W., \& Anderson, P. (2002). A structural approach to assessing innovation: Construct development of innovation locus, type, and characteristics, Management Science, 48(9), 1103-1122.

Gerbing, D.W., \& Anderson, J.C. (1988). An Updated Paradigm for Scale Development Incorporating Uni, Journal of Marketing Research, 25(2), 186-192.

Gilson, L. L., \& Shalley, C.E. (2004). A Little Creativity Goes a Long Way: An Examination of Teams’ Engagement in Creative Processes. Journal of Management, 30(4), 453 -470.

Grewal, Rajdeep, \& Rebecca J. Slotegraaf (2007), Embeddedness of Organizational Capabilities, Decision Sciences, 38, 451-488.

Grojean, M. W., Resick, C. J., Dickson, M. W., \& Smith, D. B. (2004). "Leaders, Values, and Organizational Climate: Examining Leadership Strategies for Establishing an Organizational Climate Regarding Ethics". Journal of Business Ethics, 55(3), 223-241. 
Hervas-Oliver, J.L.; Jackson, I., \& Tomlinson, P.R. (2011). May the ovens never grow cold: regional resilience and industrial policy in the North Staffordshire ceramic industrial district - with lessons from Sassuolo and Castellon. Policy Studies, 32(4), 377-395.

House, R. J., \& Shamir, B. (1993). Toward the integration of transformational, charismatic, and visionary theories. En M. M. Chemers \& R. Ayman (Eds.), Leadership theory and research: Perspectives and directions: 81-107. San Diego, CA, US: Academic Press.

Isaksen, S.G., Lauer, K.J., \& Ekvall, G. (1999), Situational outlook questionnaire: a measure of the climate for creativity and change, Psychological Reports, 85, 665-674.

James, L. R., \& McIntyre, M. D. (1996). Perceptions of organizational climate. Individual differences and behavior in organizations. San Francisco: Jossey-Bass.

Jansen, J., Van den Bosch, F.A.J. \& Volberda, H.W. (2006). Exploratory innovation, exploitative innovation, and performance: effects of organizational antecedents and environmental moderators. Management Science, 52 (11), 1661-1674.

Janssen, O. (2003). Innovative behaviour and job involvement at the price of conflict and less satisfactory relations with co-workers. Journal of Occupational and Organizational Psychology, 76(3), 347-364.

Jelinek, M. (2003). Making sense of strategic change: a problem of learning and levels. In MultiLevel Issues in Organizational Behavior and Strategy (Research in Multi Level Issues, Volume 2), Ed. Emerald Group Publishing Limited, pp. 373 - 390.

King, E.B., Chermont, K., West, M., Dawson, J.F., \& Hebl, M.R. (2007). How innovation can alleviate negative consequences of demanding work contexts: The influence of climate for innovation on organizational outcomes. Journal of Occupational and Organizational Psychology, 80(4), 631-645.

Klein, K. J., \& Knight, A. P. (2005). Innovation Implementation Overcoming the Challenge. Current Directions in Psychological Science, 14(5), 243-246.

Kuenzi, M., \& Schminke, M. (2009). Assembling Fragments Into a Lens: A Review, Critique, and Proposed Research Agenda for the Organizational Work Climate Literature. Journal of Management, 35(3), 634 -717.

Ling,Y., Simsek,Z., Lubatkin,M., \& Veiga, J. (2008). Transformational leadership's role in promoting corporate entrepreneurship: examining the CEO-TMT interface. Academy of Management Journal, 21 (3), 557-576.

Liu,K., Li, J., Hesterly, W., \& Cannella, A. (2012). Top management team tenure and technological inventions at post-IPO biotechnology firms. Journal of Business Research, 65, $1349-1356$.

Lumpkin, G. T., \& Dess, G.G. (1996). Clarifying the Entrepreneurial Orientation Construct and Linking It to Performance. Academy of Management Review, 21(1), 135-172.

Lyon, D.W., Lumpkin, G.T. \& Dess, G.G.(2000). Enhancing entrepreneurial orientation research: Operationalizing and measuring a key strategic decision making process. Journal of Management, 26(5), 1055-1085. 
Madsen, E.L. (2007). The significance of sustained entrepreneurial orientation on performance of firms - A longitudinal analysis. Entrepreneurship and Regional Development, 19(1), 185-204.

March, J.G. (1987). Learning to be risk adverse. Psychological Review, 103(2), 309-319.

Martínez-Ros, E., \& Labeaga, J.M. ( 2009). Product and process innovation: Persistence and complementarities. European Management Review, 6, 64-75.

March, J.G., \& Shapira, Z. (1987). Managerial perspectives on risk and risk taking. Management science, 33(11), 1404-1418.

Meyer-Stamer, J., Maggi, C., \& Seibel, S. (2004). Upgrading the tile industry of Italy, Spain, and Brazil: Insights from cluster and value chain analysis. In Local Enterprises in the Global Economy, Ed. Schmitz, H., Edward Elgar.

Naldi, L., Nordqvist, M., Sjöberg, K., \& Wiklund, J. (2007). Entrepreneurial orientation, Risk taking, and performance in family firms. Family Business Review, 20, 33-48.

Naumann, S. E., \& Bennett, N. (2000). A Case for Procedural Justice Climate: Development and Test of a Multilevel Model. Academy of Management Journal, 43(5), 881-889.

Nelson, R. R., \& Winter, S. G. (1985). An Evolutionary Theory of Economic Change. Belknap Press of Harvard University Press.

OECD (2005). The measurement of scientific and technological activities. Proposed guidelines for collecting and interpreting technological data. Paris: OECD.

Oldham, G. R., \& Cummings, A. (1996). Employee creativity: Personal and contextual factors at work. Academy Of Management Journal, 39(3), 607-634.

Papadakis, V.M., Lioukas, S., \& Chambers, D. (1998). Strategic decision-making process: the role of management and context. Strategic Management Journal, 19(2), 115-147.

Peterson, R.S., Smith, D.B., Martorana, P.V., \& Owens, P.D. (2003). The impact of chief executive officer personality on top management team dynamics: one mechanism by which leadership affects organizational performance. Journal of Applied Psychology, 88(5), 795808.

Pirola-Merlo, A., \& Mann, L. (2004). The relationship between individual creativity and team creativity: aggregating across people and time. Journal of Organizational Behavior, 25(2), 235-257.

Podsakoff, P. M., MacKenzie, S. B., \& Podsakoff, N. P. (2012). Sources of method bias in social science research and recommendations on how to control it. Annual Review of Psychology, $63,539-569$.

Podsakoff, P.M., MacKenzie, S.B., Lee, J., \& Podsakoff, N.P. (2003). Common method biases in behavioral research: A critical review of the literature and recommended remedies, Journal of Applied Psychology, 88(5), 879-903.

Podsakoff, P.M., \& Organ, D.W. (1986). Self-Reports in Organizational Research: Problems and Prospects, Journal of Management, 12(4), 531-544. 
Redmond, M. R., Mumford, M. D., \& Teach, R. (1993). "Putting Creativity to Work: Effects of Leader Behavior on Subordinate Creativity". Organizational Behavior and Human Decision Processes, 55(1), 120-151.

Santarelli, E., \& Piergiovanni, R. (1996). Analysing literature-based output indicators: the Italian experience. Research Policy, 25, 689-711.

Schneider, B., \& Reichers, A. E. (1983). On the Etiology of Climates. Personnel Psychology, 36(1), 19-39.

Sidhu, J.S., Volberda, H.R., \& Commandeur, H.W. (2004). Exploring Exploration Orientation and its Determinants: Some Empirical Evidence. Journal of Management Studies, 41(6), 913-932.

Sidhu, J.S., Commandeur, H.W., \& Volberda, H.R. (2007). The Multifaceted Nature of Exploration and Exploitation: Value of Supply, Demand, and Spatial Search for Innovation. Organization Science, 18(1), 20-38.

Sitkin, S. B., \& Pablo, A. L. (1992). Reconceptualizing the Determinants of Risk Behavior. Academy of Management Review, 17(1), 9-38.

Spagnoli, P., Caetano, A., \& Santos, S. C. (2012). Satisfaction with job aspects: Do patterns change over time?. Journal of Business Research, 65(5), 609-616.

Spector, P.E. (1992). Summated rating scale construction: an introduction. Sage University. California.

Spence, M. (1973). Job Market Signaling. The Quarterly Journal of Economics, 87(3), 355-374.

Teece, D., Pisano, G., \& Shuen, A. (1997). Dynamic capabilities and strategic management. Strategic Management Journal, 18 (7), 509-533.

Tippins M.J., \& Sohi, R.S. (2003). IT competency and firm performance: is organizational learning a missing link? Strategic Management Journal, 24, 745-761.

Vega-Jurado, J., Gutiérrez-Gracia, A., \& Fernández-de-Lucio, I. (2008). Analyzing the determinants of firm's absorptive capacity: beyond R\&D. R\&D Management, 38 (4), 392405.

Venkatraman, N. (1989). Strategic Orientation of Business Enterprises: The Construct, Dimensionality, and Measurement. Management Science, 35(8), 942-962.

Vroom, V. H. (1964). Work and motivation. Oxford, England: Wiley.

Wang, C. (2008). Entrepreneurial orientation, learning orientation, and firm performance. Entrepreneurship Theory and Practice, 32(4), 635-657.

Williams, L.J., Gavin, M.B., \& Hartman, N.S. (2004). Structural equation modeling methods in strategy research: Applications and issues. In Ketchen, D.J. Jr and Bergh; D.D. (Eds.) Research Methodology in Strategy and Management, Vol. 1, pp. 303-46. Oxford: Elsevier.

Woodside, A.G. (2013). Moving beyond multiple regression analysis to algorithms: Calling for adoption of a paradigm shift from symmetric to asymmetric thinking in data analysis and crafting theory. Journal of Business Research, 66(4), 463-72.

Wu,S., Levitas, E., \& Priem, R.L. (2005). CEO Tenure and Company Invention under Differing Levels of Technological Dynamism. Academy of Management Journal, 48 (5), 859-873. 
$\mathrm{Wu}, \mathrm{H}$. L. (2008). When does internal governance make firms innovative?. Journal of Business Research, 61(2), 141-153.

Yuan, F., \& Woodman, R. W. (2010). Innovative Behavior in the Workplace: The Role of Performance and Image Outcome Expectations. Academy of Management Journal, 53(2), 323342.

Zahra, S.A. \& Covin, J.G. (1995). Contextual influences on the corporate entrepreneushipperformance relationship: A longitudinal analysis. Journal of Business Venturing, 10, 4358.

Zhou, J., \& George, J. M. (2001). When job dissatisfaction leads to creativity: encouraging the expression of voice. Academy of Management Journal, 44(4), 682-696. 
Figure 1: Theoretical model

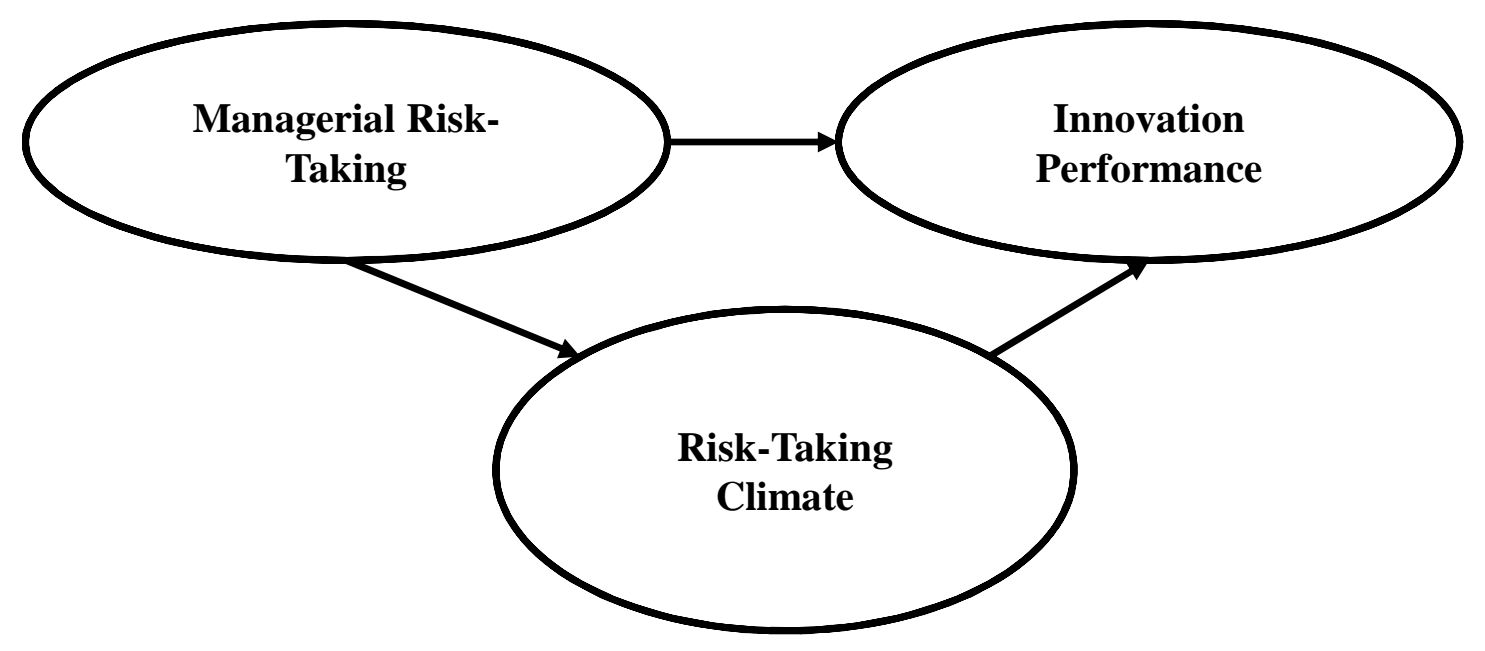

Figure 2: Confirmatory factor analysis of innovation performance

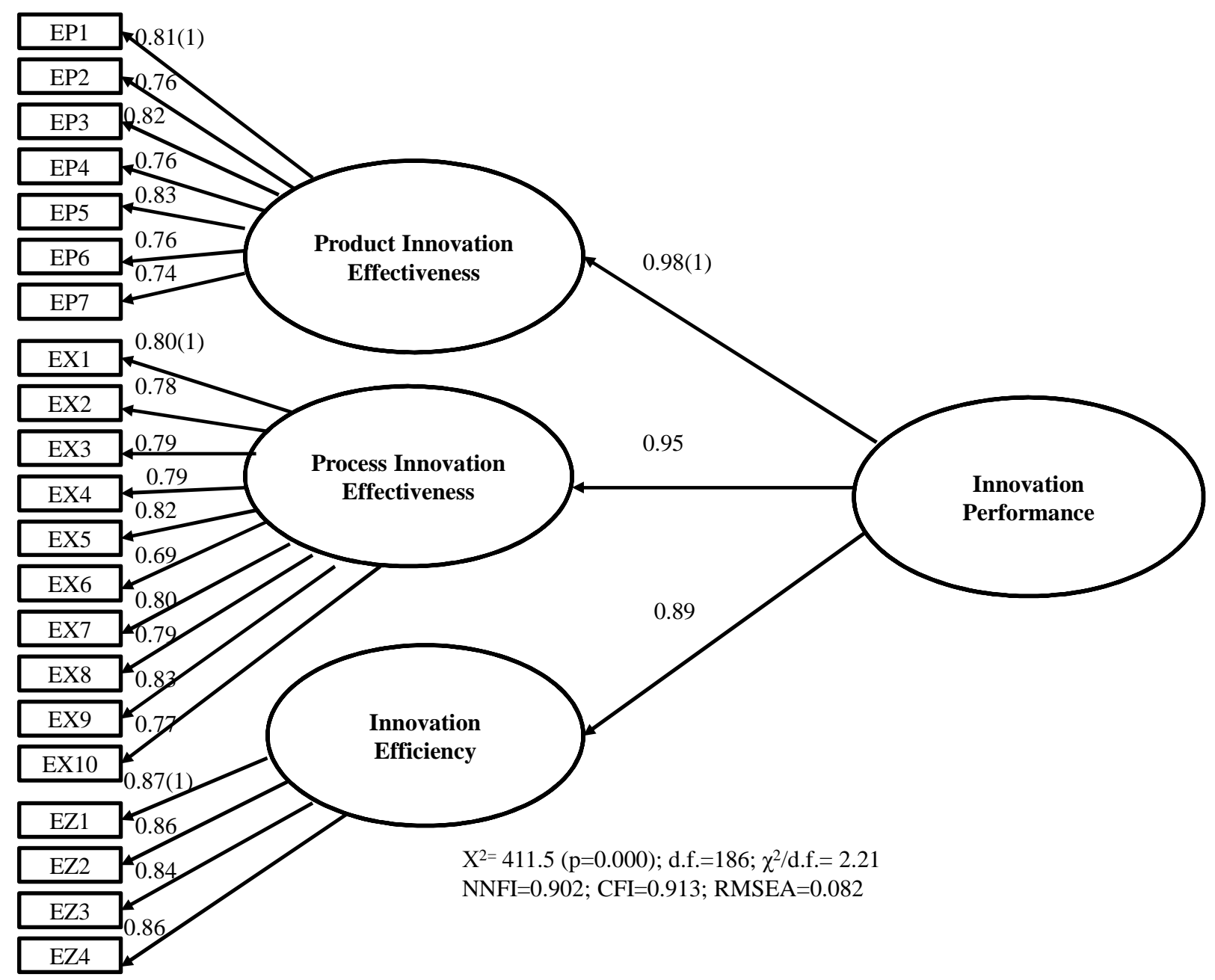


Figure 3: Direct model

$$
\mathbf{R}^{2}=0.329
$$

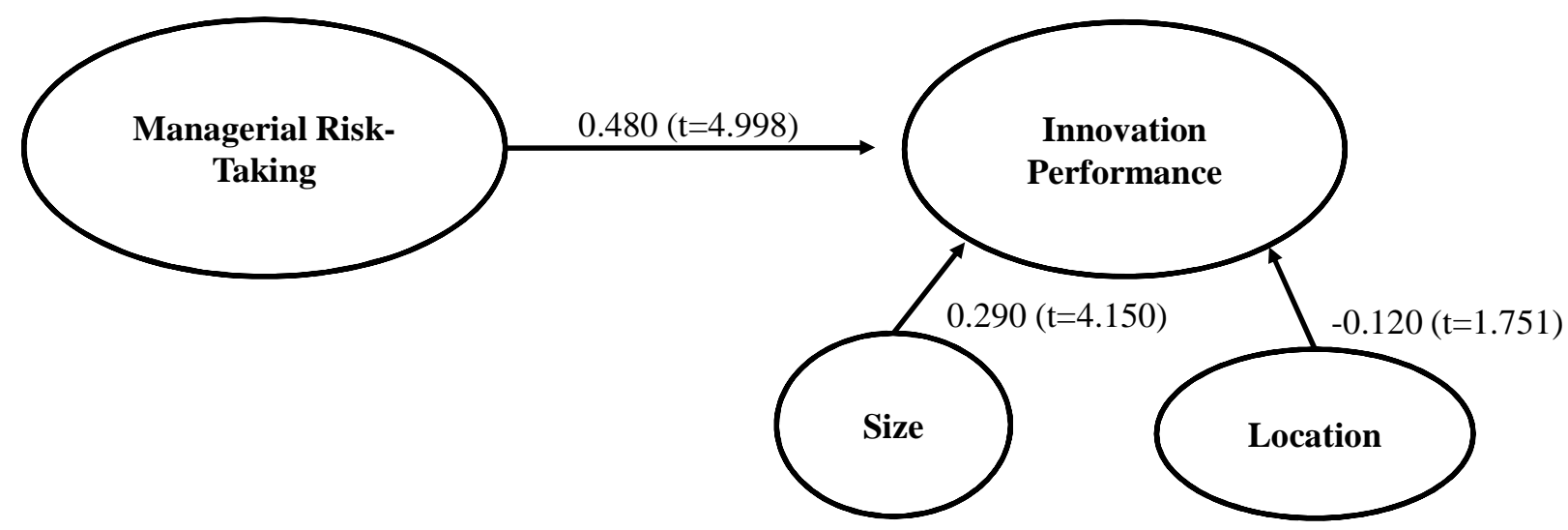

$\mathrm{X}^{2=} 594.69(\mathrm{p}=0.000) ;$ d.f. $=295 ; \mathrm{X}^{2} /$ d.f. $=2.01$

$\mathrm{NFI}=0.981 ; \mathrm{NNFI}=0.990 ; \mathrm{CFI}=0.991 ; \mathrm{RMSEA}=0.075$

Figure 4: Mediating model

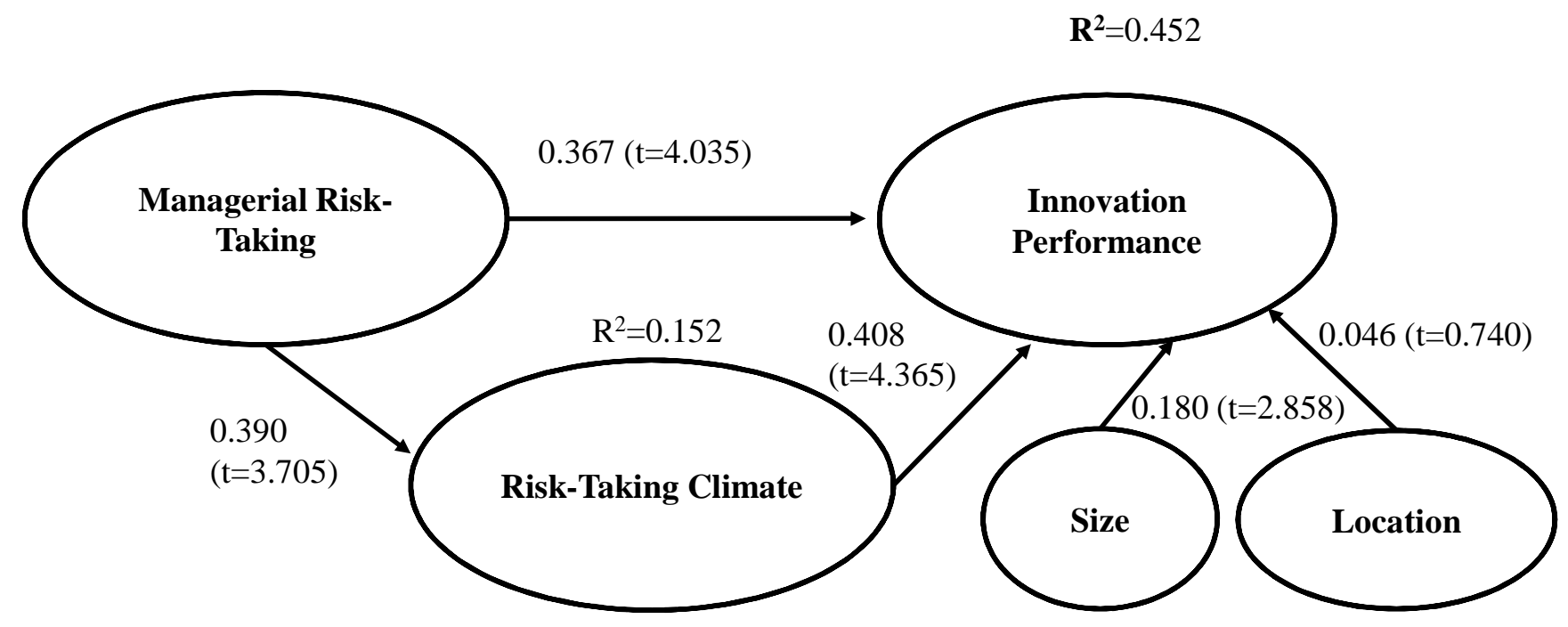

$\mathrm{X}^{2=} 862.42(\mathrm{p}=0.000) ;$ d.f. $=428 ; \mathrm{X}^{2} /$ d.f. $=2.01$

$\mathrm{NFI}=0.976 ; \mathrm{NNFI}=0.986 ; \mathrm{CFI}=0.988 ; \mathrm{RMSEA}=0.075$ 
Table 1: Factors correlations, means, standard deviations, Cronbach's alphas and Composite Reliabilities

\begin{tabular}{|l|c|c|c|c|c|c|c|c|c|}
\hline & Mean & s.d. & CR & $\mathbf{1}$ & $\mathbf{2}$ & $\mathbf{3}$ & $\mathbf{4}$ & $\mathbf{5}$ & $\mathbf{6}$ \\
\hline 1. Risk-taking climate & 4,84 & 1,13 & 0,83 & $(0,83)$ & & & & & \\
\hline 2. Managerial risk-taking propensity & 3,89 & 1,31 & 0,74 & $0,313^{* * *}$ & $(0,74)$ & & & & \\
\hline 3. Product innovation effectiveness & 5,07 & 1,11 & 0,91 & $0,471^{* *}$ & $0,485^{* *}$ & $(0,92)$ & & & \\
\hline 4. Process innovation effectiveness & 4,9 & 1,12 & 0,94 & $0,462^{* *}$ & $0.366^{* *}$ & $0.846^{* *}$ & $(0,94)$ & & \\
\hline 5. Process innovation efficiency & 4,69 & 1,22 & 0,92 & $0,563^{* *}$ & $0,489^{* *}$ & $0,797^{* *}$ & $0,782^{* *}$ & $(0,92)$ & \\
\hline 6. Size & 3.49 & 1,41 & - & $0,409^{* *}$ & $0,318^{* *}$ & $0,345^{* *}$ & $0,450^{* *}$ & $0,398^{* *}$ & - \\
\hline 7. Country & 1.55 & 0.50 & - & $-0,463^{* *}$ & $-0,073$ & $-0,102$ & $-0,214^{* *}$ & $-0,369^{* *}$ & $-0,258^{* *}$ \\
\hline
\end{tabular}

** Statistically significant correlation coefficient $(\mathrm{p}<0,01)$

Cronbach's alpha shown on the diagonal. Composite reliabilities are shown in the CR column

To calculate the correlation coefficients, we worked with the means of the items that make up each dimension 


\section{Innovation Performance Measurement Scale}

Please state your firm performance compared to that of your competitors over the last three years with regard to the following items

\begin{tabular}{|c|c|c|}
\hline Dimension & Item & Literature source \\
\hline \multirow{7}{*}{$\begin{array}{l}\text { Product } \\
\text { innovation } \\
\text { effectiveness }\end{array}$} & PT1. Replacement of products being phased out & \multirow{21}{*}{$\begin{array}{l}\text { OECD (2005); } \\
\text { Brown and } \\
\text { Eisenhardt (1995); } \\
\text { Chiesa et al. (1996) }\end{array}$} \\
\hline & $\begin{array}{l}\text { PT2. Extension of product range within main product } \\
\text { field through new products }\end{array}$ & \\
\hline & $\begin{array}{l}\text { PT3. Extension of product range outside main } \\
\text { product field }\end{array}$ & \\
\hline & PT4. Development of environment-friendly products & \\
\hline & PT5. Market share evolution & \\
\hline & PT6. Opening of new markets abroad & \\
\hline & PT7. Opening of new domestic target groups & \\
\hline \multirow{10}{*}{$\begin{array}{l}\text { Process } \\
\text { innovation } \\
\text { effectiveness }\end{array}$} & PS1. Improvement of production flexibility & \\
\hline & $\begin{array}{l}\text { PS2. Reduction of production costs by cutting labor } \\
\text { cost per unit }\end{array}$ & \\
\hline & $\begin{array}{l}\text { PS3. Reduction of production costs by cutting } \\
\text { material consumption }\end{array}$ & \\
\hline & $\begin{array}{l}\text { PS4. Reduction of production costs by cutting energy } \\
\text { consumption }\end{array}$ & \\
\hline & $\begin{array}{l}\text { PS5. Reduction of production costs by cutting } \\
\text { rejected production rate }\end{array}$ & \\
\hline & $\begin{array}{l}\text { PS6. Reduction of production costs by cutting design } \\
\text { costs }\end{array}$ & \\
\hline & $\begin{array}{l}\text { PS7. Reduction of production costs by cutting } \\
\text { production cycle }\end{array}$ & \\
\hline & PS8. Improvement of product quality & \\
\hline & PS9. Improvement of labor conditions & \\
\hline & PS10. Reduction of environmental damage & \\
\hline \multirow{4}{*}{$\begin{array}{l}\text { Project } \\
\text { innovation } \\
\text { efficiency }\end{array}$} & EF1. Average innovation project development time & \\
\hline & $\begin{array}{l}\text { EF2. Average number of innovation project working } \\
\text { hours }\end{array}$ & \\
\hline & EF3. Average cost per innovation project & \\
\hline & $\begin{array}{l}\text { EF4. Degree of overall satisfaction with innovation } \\
\text { project efficiency }\end{array}$ & \\
\hline
\end{tabular}

